\author{
Danuta Idzikowska \\ University of Warsaw \\ Faculty of Geography and Regional Studies \\ Department of Climatology \\ e-mail: danuta.idzikowska@student.uw.edu.pl
}

\title{
BIOCLIMATIC CONDITIONS OF PARIS, ROME AND BUDAPEST ON THE BASIS OF THE UNIVERSAL THERMAL CLIMATE INDEX
}

\begin{abstract}
The aim of this study was to examine the main features of the bioclimatic conditions of three European cities using a new Universal Thermal Climate Index. Daily values of meteorological variables for 12 UTC for the cities for 1990-2001 were used in the study. Using the frequency of UTCI and one-way Anova, the results showed that in all the three cities "no thermal stress" dominated throughout the year. "Extreme" values of heat as well as "cold stress" were observed but in none of the cities "extreme cold stress" occurred. The values of UTCI differed for all the three cities in each studied year. The cities differed from each other in each month during the whole year with the exception of spring - March and April.
\end{abstract}

Key words: bioclimate, UTCI, Paris, Rome, Budapest.

\section{INTRODUCTION}

It is commonly known that climate and weather influence human beings in many ways. Therefore, it is of great importance to deliver information about the bioclimatic conditions of the cities which are densely populated so as to indirectly help people improve their living conditions.

The importance of outdoor urban climate is neglected by planners and architects due to the lack of knowledge about the influence of urban structure and building design on the climate and the lack of methods and measures to evaluate climatic impacts on human health and well-being (Taesler R., 1991)

Unfortunately, not much research has been done concerning the bioclimatic conditions of Paris, Rome and Budapest. Usually, the temperature-related factors are examined. For example, J. Amigo and C. Ramirez (1998) marked the macrobioclimatic regions of Chile on the basis of the temperature and precipitation regime. To assess thermal environment, different biometeoro- 
logical indices such as Humidex or the Wind Chill Index as well as heat budget models such as Missenard's effective temperature (Jauregui et al., 1997) or Predicted Mean Vote (Matzarakis, Mayer, 1997) are used. In the present study, the Universal Thermal Climate Index (UTCI) was used for the first time. For each index value, there is a corresponding and unique thermo-physiological state of the human organism. UTCI equivalent temperature was categorised in terms of thermal stress (Table 1).

Table 1. UTCI categorised in terms of thermal stress

\begin{tabular}{|c|l|}
\hline UTCI $\left({ }^{\circ} \mathrm{C}\right)$ range & Stress category \\
\hline above +46 & extreme heat stress \\
\hline $38.1-46.0$ & very high heat stress \\
\hline $32.1-38.0$ & high heat stress \\
\hline $26.1-32.0$ & moderate heat stress \\
\hline $9.1-26.0$ & no thermal stress \\
\hline $0.1-9.0$ & slight cold stress \\
\hline$-12.9-0.0$ & moderate cold stress \\
\hline$-26.9 \div 13.0$ & high cold stress \\
\hline$-39.9 \div 27.0$ & very high cold stress \\
\hline$\leq-40$ & extreme cold stress \\
\hline
\end{tabular}

UTCI can be calculated using different input data, and therefore it can be adapted for the needs of different users. It may also be applied in many scientific fields such as weather forecasts for the general public, forecasts of thermal extremes, epidemiology, bioclimate mapping, urban bioclimatology and planning, tourism and recreation, climate change impact research or climate therapy (Jendritzky et al., 2009; Błażejczyk et al., 2009).

\section{MATERIALS AND METHODS}

\section{Meteorological data}

The meteorological data used in the study came from the database created for the Assessment and Prevention of Acute Health Effects of Weather Conditions in Europe (PHEWE) project.

The data used in the study consists of the daily values of air temperature, dew point temperature, wind speed $(\mathrm{m} / \mathrm{s})$, total cloud cover (octas) and relative humidity for 12 UTC for Paris, Rome and Budapest for the period 1990-2001. The period 1992-1999 was chosen for comparison.

\section{Methods}

On the basis of the above data, the Universal Thermal Climate Index (UTCI) for each single day was calculated using BioKlima v. 2.5 software and the UTCI calculator (Błażejczyk et al., 2009). 
For the statistical analysis frequency of UTCI in certain categories as well as one-way Anova was used.

\section{Climate characteristic of the cities}

Paris is situated in the Paris Basin at the latitude of $48^{\circ} 58^{\prime} \mathrm{N}, 33 \mathrm{~m}$ above the sea level and within the temperate warm maritime climate zone. The mean temperature varies from about $3.4^{\circ} \mathrm{C}$ in January to about $18.4^{\circ} \mathrm{C}$ in July. The precipitation remains at approximately the same level throughout the year, with the annual total of $650 \mathrm{~mm}$ (CLINO, 1996).

Rome is situated in the middle of the highlands of central Italy at the latitude of $41^{\circ} 54$ ' N, $37 \mathrm{~m}$ above the sea level and has a subtropical climate. The maximum temperature is the highest in August (about $28^{\circ} \mathrm{C}$ ) and the lowest in December and January (about $13^{\circ} \mathrm{C}$ ). The minimum temperature reaches its peak in July and August $\left(18^{\circ} \mathrm{C}\right)$, and its lowest point is in January $\left(3^{\circ} \mathrm{C}\right)$. The annual total of precipitation is $740 \mathrm{~mm}$ (http://www.ncdc.noaa. gov/oa/documentlibrary/).

Budapest is situated in the north of Hungary on the Danube river at the latitude of $47^{\circ} 30^{\prime} \mathrm{N}, 102 \mathrm{~m}$ above the sea level and within the temperate warm climate zone. The mean temperature is the highest in July $\left(20,8^{\circ} \mathrm{C}\right)$ and the lowest in January $\left(-1,6^{\circ} \mathrm{C}\right)$. The annual total of precipitation is 516 $\mathrm{mm}$ (CLINO, 1996).

The three cities have been chosen for the study due to their location in different parts of Europe and consequently in different climates.

\section{RESULTS AND DISCUSSION}

In all the three cities, UTCI most frequently reached values in the category "no thermal stress", ranging from $+9^{\circ} \mathrm{C}$ to $+26^{\circ} \mathrm{C}$ (Fig. 1). More than $50 \%$ of such cases were recorded in Rome whereas in Paris and Budapest it was $39 \%$ and $38 \%$, respectively. In Paris, UTCI very often indicated "moderate cold stress" (25\%) and "slight cold stress" (23\%). The situation was similar in Budapest where "moderate cold stress" and "slight cold stress" reached $20 \%$ in both cases. It could have been caused by the fact that Paris is situated in the temperate warm maritime climate affected by the cooling effect of the Atlantic Ocean. Budapest has a temperate warm climate but it is situated in the mainland and therefore the continental air masses might have come to the region with a similar effect as in Paris. Similar results were obtained by Matzarakis et al. (2009) for Entzheim (rural town in France), where cold temperatures, analysed through the frequency of thermal sensitivity and the grade of thermal stress $(P E T)$, dominated throughout the whole year. However, in Rome, which represents the subtropical climate zone, it was "moderate heat stress" (UTCI from $+26^{\circ} \mathrm{C}$ to $+32^{\circ} \mathrm{C}-18 \%$ ) that occurred the most frequently after "no thermal stress". "Slight cold stress" and "high heat stress" occurred in Rome with a similar frequency, of $14 \%$ 
and $11 \%$, respectively. An analysis of the extreme cases in the three cities revealed that it was only Rome and Budapest where UTCI achieved "very high heat stress" (1\% in both), and in Rome there was one day with UTCI above $+46^{\circ} \mathrm{C}$, which corresponds to "extreme heat stress". Considering the cold extremes, in Paris (4\%) and Budapest (2\%) "high cold stress" (UTCI from $-13^{\circ} \mathrm{C}$ to $-27^{\circ} \mathrm{C}$ ) was noted (Fig. 1). There were also 7 days in Paris and 2 in Budapest with "very high cold stress" (UTCI from $-27^{\circ} \mathrm{C}$ to $-40^{\circ} \mathrm{C}$ ). Such days did not appear in Rome. "Extreme cold stress" (UTCI $\leq-40^{\circ} \mathrm{C}$ ) could not be observed in any of the cities. A thorough analysis of UTCI in different classes in different months may show further and more detailed results and improve the conclusions drawn.

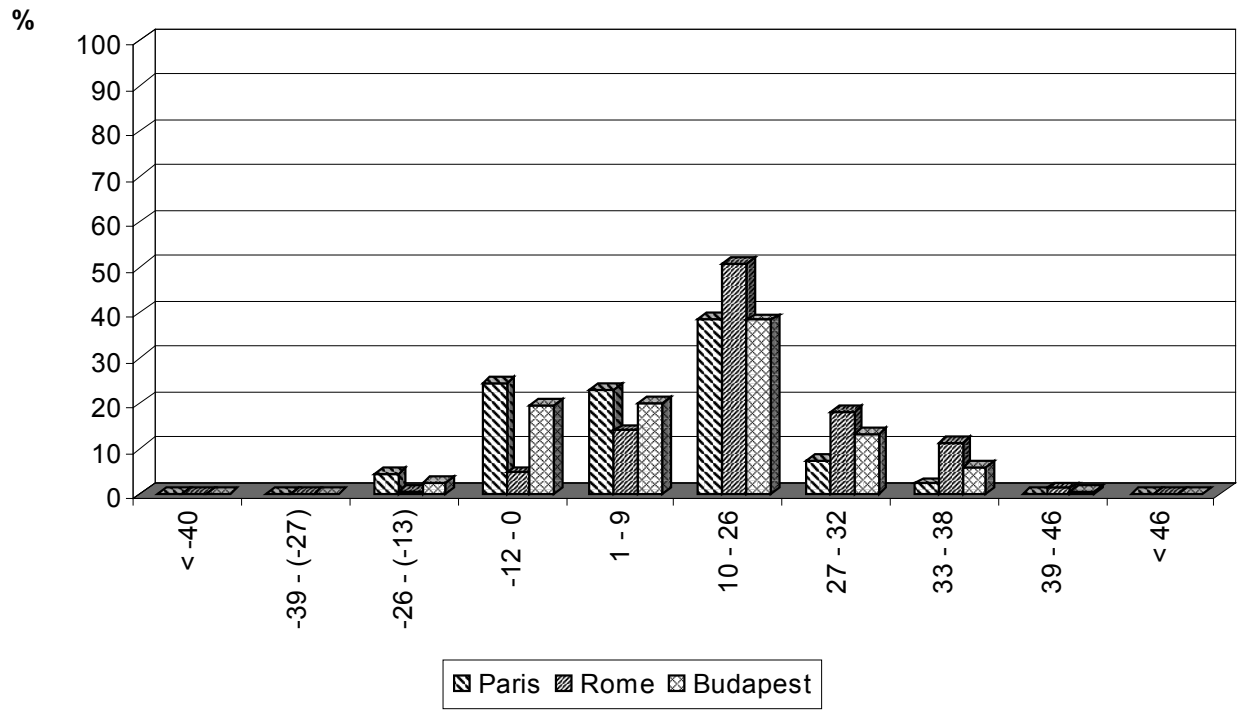

Fig.1. The frequency of UTCI in Paris, Rome and Budapest in 1990-2001

The average value of UTCI was calculated for each year for all the three cities. The data for 1990 and 1991 was accessible only for Paris and it was impossible to compare it with the other two cities. Similarly, there was no data for 2000 for Paris and for 2001 for Paris and Rome. The comparable period for the three cities was 1992-1999. As shown in table 2, the values of UTCI differed for all the three cities in each analysed year at the significance level of 0.05 . Budapest was always the closest to the mean value of UTCI for the three cities. The value of UTCI for Rome was above the mean, and for Paris - below it. It can be explained by the fact that Rome is situated at lower latitudes $\left(41^{\circ} 54^{\prime} \mathrm{N}\right)$ than Paris $\left(48^{\circ} 58^{\prime} \mathrm{N}\right)$ and Budapest $\left(47^{\circ} 30^{\prime} \mathrm{N}\right)$, and consequently has a warmer climate. 
Table 2. UTCI differences between Paris, Rome and Budapest by year

\begin{tabular}{|c|c|c|c|c|c|c|}
\hline \multirow{2}{*}{ Year } & \multicolumn{3}{|c|}{ City } & \multirow{2}{*}{ Mean } & \multirow{2}{*}{$\mathrm{SE}$} & \multirow{2}{*}{$<\mathrm{P}$} \\
\hline & Paris & Rome & Budapest & & & \\
\hline 1990 & 9.48 & - & - & & & \\
\hline 1991 & 8.68 & - & - & & & \\
\hline 1992 & $8.13^{\mathrm{A}}$ & $18.74^{\mathrm{B}}$ & $12.77^{\mathrm{C}}$ & 13.22 & 0.66 & $* * *$ \\
\hline 1993 & $6.94^{\mathrm{A}}$ & $18.31^{\mathrm{B}}$ & $11.77^{\mathrm{C}}$ & 12.34 & 0.66 & $* * *$ \\
\hline 1994 & $8.95^{\mathrm{A}}$ & $19.60^{\mathrm{B}}$ & $13.14^{\mathrm{C}}$ & 13.90 & 0.66 & $* * *$ \\
\hline 1995 & $9.01^{\mathrm{A}}$ & $17.79^{\mathrm{B}}$ & $11.26^{\mathrm{C}}$ & 12.69 & 0.69 & $* * *$ \\
\hline 1996 & $6.42^{\mathrm{A}}$ & $17.89^{\mathrm{B}}$ & $11.12^{\mathrm{C}}$ & 11.81 & 0.67 & $* * *$ \\
\hline 1997 & $9.68^{\mathrm{A}}$ & $19.66^{\mathrm{B}}$ & $12.23^{\mathrm{C}}$ & 13.85 & 0.65 & $* * *$ \\
\hline 1998 & $7.10^{\mathrm{A}}$ & $20.21^{\mathrm{B}}$ & $12.17^{\mathrm{C}}$ & 13.16 & 0.63 & $* * *$ \\
\hline 1999 & $8.31^{\mathrm{A}}$ & $18.80^{\mathrm{B}}$ & $11.94^{\mathrm{C}}$ & 12.94 & 0.67 & $* * *$ \\
\hline 2000 & - & 19.48 & 14.28 & & & \\
\hline 2001 & - & - & 12.71 & & & \\
\hline
\end{tabular}

$\mathrm{SE}$ - standard error

A,B,C - significantly different groups at $\mathrm{P}<0.001 ;{ }^{* * *}-\mathrm{P}<0.001$

The average value of UTCI was also calculated for each month for the three cities. The cities differed from each other during the whole year at the significance level of 0.05, except for March and April. Table 3 shows that in March Rome $\left(12.11^{\circ} \mathrm{C}\right)$ differed from Paris $\left(3.34^{\circ} \mathrm{C}\right)$ and Budapest $\left(4.17^{\circ} \mathrm{C}\right)$, but the latter two did not. However, in April it was Paris $\left(6.61^{\circ} \mathrm{C}\right)$ which had a much lower UTCI value than Rome $\left(13.65^{\circ} \mathrm{C}\right)$ and Budapest $\left(12.38^{\circ} \mathrm{C}\right)$. It might have been caused by different air masses coming over the cities which change very often during spring time. The cities might also be divided into two groups in terms of thermal conditions felt by individuals. The first one, with cold winters and comfort summers, includes Paris, while the second one, with cold or cool winters and hot summers, includes Rome and Budapest. In winter, the regional differentiation of bio-thermal conditions among the three cities is greater than in summer. For example, Budapest is exposed to cold arctic or continental air masses (Błażejczyk, McGregor, 2007).

\section{CONCLUSIONS}

The UTCI has been used to describe the general features of the bioclimate of Paris, Rome and Budapest.

First of all, UTCI frequency in different stress categories was calculated. It showed that in all the three cities "no thermal stress" dominates throughout the year. Additionally, in Paris and Budapest "moderate" and "slight 
Table 3. UTCI differences between Paris, Rome and Budapest by month

\begin{tabular}{|c|c|c|c|c|c|c|}
\hline \multirow{2}{*}{ Month } & \multicolumn{3}{|c|}{ City } & \multirow{2}{*}{ Mean } & SE & \multirow{2}{*}{$<$} \\
\cline { 2 - 4 } & Paris & Rome & Budapest & & \\
\hline 1 & $-6.11^{\mathrm{A}}$ & $7.92^{\mathrm{B}}$ & $-3.12^{\mathrm{C}}$ & -0.73 & 0.44 & $* * *$ \\
\hline 2 & $-2.69^{\mathrm{A}}$ & $10.08^{\mathrm{B}}$ & $-0.12^{\mathrm{C}}$ & 2.15 & 0.50 & $* * *$ \\
\hline 3 & $3.34^{\mathrm{A}}$ & $12.11^{\mathrm{B}}$ & $4.17^{\mathrm{A}}$ & 6.32 & 0.49 & $* * *$ \\
\hline 4 & $6.61^{\mathrm{A}}$ & $13.65^{\mathrm{B}}$ & $12.38^{\mathrm{B}}$ & 10.78 & 0.51 & $* * *$ \\
\hline 5 & $15.11^{\mathrm{A}}$ & $22.59^{\mathrm{B}}$ & $21.21^{\mathrm{C}}$ & 19.53 & 0.42 & $* * *$ \\
\hline 6 & $17.45^{\mathrm{A}}$ & $27.33^{\mathrm{B}}$ & $24.42^{\mathrm{C}}$ & 22.91 & 0.40 & $* * *$ \\
\hline 7 & $22.23^{\mathrm{A}}$ & $31.35^{\mathrm{B}}$ & $26.94^{\mathrm{C}}$ & 26.67 & 0.39 & $* * *$ \\
\hline 8 & $23.52^{\mathrm{A}}$ & $32.99^{\mathrm{B}}$ & $28.55^{\mathrm{C}}$ & 28.18 & 0.38 & $* * *$ \\
\hline 9 & $15.64^{\mathrm{A}}$ & $26.33^{\mathrm{B}}$ & $19.59^{\mathrm{C}}$ & 20.32 & 0.39 & $* * *$ \\
\hline 10 & $8.71^{\mathrm{A}}$ & $20.60^{\mathrm{B}}$ & $14.28^{\mathrm{C}}$ & 14.31 & 0.44 & $* * *$ \\
\hline 11 & $0.41^{\mathrm{A}}$ & $13.17^{\mathrm{B}}$ & $2.75^{\mathrm{C}}$ & 5.17 & 0.44 & $* * *$ \\
\hline 12 & $-5.75^{\mathrm{A}}$ & $8.35^{\mathrm{B}}$ & $-3.75^{\mathrm{C}}$ & -0.75 & 0.42 & $* * *$ \\
\hline
\end{tabular}

$\mathrm{SE}$ - standard error

$\mathrm{A}, \mathrm{B}, \mathrm{C}-$ significantly different groups at $\mathrm{P}<0.001 ; * * *-\mathrm{P}<0.001$

cold stress" often appeared. However, in Rome "moderate heat stress" was more frequent. Extreme values of heat could be observed in Rome and Budapest. Cold stress was observed in Paris and Budapest but in none of the cities "extreme cold stress" was recorded.

Secondly, the average value of UTCI was calculated for each year for all the three cities. The values of UTCI differed for all the three cities in each studied year. Budapest was the closest to the mean value of UTCI for the three cities. The UTCI value for Rome was above the mean, and for Paris - below it. The reason for such a situation maybe the location of the cities and subsequently the differences in their climates.

Thirdly, the average value of UTCI was calculated for each month for the three cities. The cities differed from each other during the whole year. Spring time appeared to be exceptional in March, when Paris and Budapest had similar values of UTCI, and April, when Paris had much lower UTCI values than the two other cities.

\section{ACKNOWLEDGEMENTS}

The data for the study was obtained thanks to Professor Krzysztof Błażejczyk from the Faculty of Geography and Regional Studies, University of Warsaw and Glen McGregor, PhD, from the University of Auckland (New Zealand). 


\section{REFERENCES}

Amigo J., Ramirez C., 1998, A bioclimatic classification of Chile: woodland communities in the temperate zone, Plant Ecology 136, 9-26.

Błażejczyk K., McGregor G., 2007, Warunki biotermiczne a umieralność w wybranych aglomeracjach europejskich [Biothermal conditions and the death rate in selected European agglomerations], Przeglad Geograficzny 79, 3 and 4, 401-423.

Błażejczyk K., Broede P., Fiala D, Havenith G., Holmér I., Jendritzky G., Kampmann B., Kunert A., 2009, Principles of the new Universal Thermal Climate Index (UTCI) and its application to bioclimatic research in European scale, Miscellanea Geographica, 14, 91-102.

Climatological normals (CLINO) for the period 1961-1990, 1996, WMO, 847, Geneva.

Jauregui E., Cervantes J., Tejeda A., 1997, Bioclimatic conditions in Mexico City - an assessment, International Journal of Biometeorology 40, 166-177.

Jendritzky G., Havenith G., Weihs P., Batchvarova E. (eds.), 2009, Towards a Universal Thermal Climate Index UTCI for assessing the thermal environment of the human being. Final Report, COST Action 730.

Matzarakis A., De Rocco M., Najjar G., 2009, Thermal bioclimate in Strasbourg - the 2003 heat wave, Theoretical and Applied Climatology 98, 209-220.

Matzarakis A., Mayer H., 1997, Heat stress in Greece, International Journal of Biometeorology 41, 34-39.

Taesler R., 1991, The bioclimate in temperate and northern cities, International Journal of Biometeorology 35, 161-168.

Internet source: http://www.ncdc.noaa.gov/oa/documentlibrary (20.09.2009). 